\title{
Tobacco endgame is when the industry screams for its life
}

\author{
E Ulysses Dorotheo
}

Southeast Asia Tobacco Control Alliance, Bangkok, Thailand

\section{Correspondence to}

Dr E Ulysses Dorotheo, Southeast Asia Tobacco Control Alliance, Bangkok 10300, Thailand; ulysses@seatca.org

\section{Check for updates}

(c) Author(s) (or their employer(s)) 2022. No commercial re-use. See rights and permissions. Published by BMJ.

To cite: Dorotheo EU.

Tob Control 2022;31:384.
'He who does not know how to look back at where he came from will never get to his destination.' - Dr Jose Rizal

It's amazing that governments the world over are working overtime to control the COVID-19 pandemic yet tolerate and seemingly neglect (and some even abet) the tobacco pandemic. If the world responded to the tobacco pandemic (that annually kills 8.2 million people) in the same way it has COVID-19 (that has killed 5.5 million over the past 24 months), wouldn't we realise the tobacco endgame sooner than later?

Clearly, this hasn't happened, because the tobacco industry has convinced the world that tobacco use is normal and that the tobacco industry should be allowed and even encouraged to continue its 'socially responsible' business (totally false) ${ }^{1}$ while providing tax revenues and jobs. Apparently, many have forgotten and not learnt from the tobacco industry conspiracy against humanity, ${ }^{2-4}$ while the industry has learnt and adapted, because it knows its future is at stake. To bolster its false claim as a legitimate stakeholder in tobacco control, it has invested billions beyond developing reportedly less harmful products or spinning its image as a transformed, more responsible and science-based industry. For example, the Philip Morris funded Foundation for a Smoke-free World isn't just another industry front group but one that's stolen 'smoke-free' terminology to 'accelerate the end of smoking' and co-opted tobacco control advocates in its narrative. ${ }^{5}$

Donning the electronic robes of a false messiah while continuing to drive the tobacco pandemic and oppose evidence-based tobacco control measures, industry has gone as far as proclaiming that tobacco control has failed to reduce smoking, that hardened smokers have a right to switch to 'less harmful' products, despite the hardening hypothesis remaining unproven, ${ }^{6-8}$ that nicotine's as benign as caffeine and that tobacco control advocates are manufacturing scientific evidence while denying the science of its newer 'smoke-free' products.

Sadly, many have accepted the industry's definition of acceptable harm, placing debatable harm reduction front and centre, attempting to redefine the endgame and sidelining proven policy measures that would accelerate a genuine endgame: reducing affordability through taxes, comprehensive marketing bans, 100\% smoke-free environments, standardised packaging, flavour bans, ${ }^{9}$ single-variant presentation, ${ }^{10}$ limiting retail access, ${ }^{11}$ phasing out cigarette sales ${ }^{12}$ and preventing a new generation of nicotine addiction (eg, raising the minimum legal age or legislating a tobacco-free generation ${ }^{13}$ ).

This is the real threat to tobacco control's future. Have we lost sight of the endgame and ceded control of it to the industry? Are we content to allow the industry to do business as usual? We owe it to future generations to make the industry scream for its life.

\section{Contributors EUD is the sole contributor of this article.}

Funding The authors have not declared a specific grant for this research from any funding agency in the public, commercial or not-for-profit sectors.

Competing interests None declared.

Patient consent for publication Not applicable.

Ethics approval This study does not involve human participants.

Provenance and peer review Commissioned; internally peer reviewed.

ORCID iD

E Ulysses Dorotheo http://orcid.org/0000-0002-6171-6550

\section{REFERENCES}

1 Toebes B. Human rights and the tobacco industry: an unsuitable alliance. Int J Health Policy Manag 2018;7:677.

2 Cummings KM, Morley CP, Hyland A. Failed promises of the cigarette industry and its effect on consumer misperceptions about the health risks of smoking. Tob Control 2002;11 Suppl 1:i110-7.

3 Francey N, Chapman S. "Operation Berkshire": the international tobacco companies' conspiracy. BMJ 2000;321:371-4.

4 Saloojee Y, Dagli E. Tobacco industry tactics for resisting public policy on health. Bull World Health Organ 2000;78:902-10.

5 Malone RE, Chapman S, Gupta PC, et al. A "Frank Statement" for the 21st Century? Tob Control 2017;26:611-2.

6 Feliu A, Fernandez E, Martinez C, et al. Are smokers "hardening" or rather "softening"? An ecological and multilevel analysis across 28 European Union countries. Eur Respir J 2019;54:1900596.

7 Cohen JE, McDonald PW, Selby P. Softening up on the hardening hypothesis. Tob Control 2012;21:265-6.

8 Skinner A, Occhipinti J-A, Osgood ND. A dynamic modelling analysis of the impact of tobacco control programs on population-level nicotine dependence. Sci Rep 2021;11:1866.

9 Erinoso 0, Clegg Smith K, lacobelli M, et al. Global review of tobacco product flavour policies. Tob Control 2021;30:373-9.

10 DeAtley T, Bianco E, Welding K, et al. Compliance with Uruguay's single presentation requirement. Tob Control 2018;27:220-4.

11 Ackerman A, Etow A, Bartel S, et al. Reducing the density and number of tobacco retailers: policy solutions and legal issues. Nicotine Tob Res 2017;19:133-40.

12 Smith EA, Malone RE. An argument for phasing out sales of cigarettes. Tob Control 2020;29:703-8.

13 Berrick AJ. The tobacco-free generation proposal. Tob Control 2013;22 Suppl 1:i22-6. 